\title{
Herbaceous Vegetation Responses (1992-2004) to Restoration Treatments in a Ponderosa Pine Forest
}

\author{
Margaret M. Moore, ${ }^{1}$ Cheryl A. Casey, ${ }^{1}$ Jonathan D. Bakker, ${ }^{1,2}$ Judith D. Springer, ${ }^{2}$ \\ Peter Z. Fule, ${ }^{1,2}$ W. Wallace Covington, ${ }^{1,2}$ and Daniel C. Laughlin ${ }^{2}$ \\ Authors are ${ }^{1}$ School of Forestry, Northern Arizona University, Flagstaff, AZ 86011; and \\ ${ }^{2}$ Ecological Restoration Institute, Northern Arizona University, Flagstaff, AZ 86011.
}

\begin{abstract}
Ecological restoration treatments are widely applied in southwestern ponderosa pine forests to convert them to an open canopy structure similar to that found at the time of Euro-American settlement. An experiment was initiated in northern Arizona in 1994 to evaluate long-term ecosystem responses to 3 restoration treatments: 1) thinning from below (thinning), 2) thinning from below plus forest floor manipulation with periodic prescribed burning (composite), and 3) an untreated control. Results focus on total herbaceous and functional-group standing crop response to these restoration treatments. Pretreatment data were collected in 1992 and posttreatment responses were measured from 1994 through 2004. Total herbaceous standing crop was significantly higher on the 2 treated areas than on the control over the entire posttreatment period, but did not differ between the thinning and composite treatments. Plant functional groups responded differently to treatments and to drought. In general, the graminoid standing crop responded within several years after the initial treatments and continued to increase through time, until a series of severe droughts reduced standing crop to pretreatment levels. $\mathrm{C}_{3}$ graminoids dominated the standing-crop response, of which bottlebrush squirreltail (Elymus elymoides (Raf.) Swezey ssp. elymoides) was the primary contributor. $\mathrm{C}_{4}$ graminoids had a minimal response to restoration treatments, possibly because they were less abundant before the experiment began or because they were adversely affected by autumn burning. Legumes and forbs exhibited a 4-5 year lag before responding to the thinning and composite treatments. Annual and biennial plants showed a large biomass increase approximately 5 years after implementation of the composite treatment. The restoration goal of optimizing herbaceous standing crop must be weighed against the competing goals of increasing the abundance of specific functional groups, increasing biodiversity or rare plants, and managing invasive plant species.
\end{abstract}

\section{Resumen}

Los tratamientos de restauración ecológica son ampliamente aplicados en los bosques de "Ponderosa pine" del sudoeste para convertirlos en una estructura de cobertura abierta similar a la que se encontró en el tiempo de la colonización Euroamericana. En 1994, en el norte de Arizona, se inicio un experimento para evaluar las respuestas a largo lazo del ecosistema a tres tratamientos de restauración: 1) aclareo desde abajo (aclareo); 2) Aclareo desde abajo mas manipulación del piso del bosque con fuego prescrito periódico (compuesto) y 3) control sin tratar. Los resultados se enfocaron en la respuesta de la biomasa total herbácea y de grupos funcionales a estos tratamientos de restauración. Los datos pre-tratamiento fueron colectados en 1992 y las respuestas post-tratamientos fueron medidas de 1994 a 2004. Durante todo el periodo post-tratamiento la biomasa total herbácea de las dos áreas tratadas fue significativamente mayor que la del área control, pero no difirió entre los tratamientos de aclareo y compuesto. Los grupos funcionales de plantas respondieron diferente a los tratamientos y la sequía. En general, la biomasa de las gramíneas respondió varios años después de iniciar los tratamientos, incrementándose continuamente a través del tiempo hasta que una serie de severas sequías redujo la biomasa a los niveles presentes antes de aplicar los tratamientos. Las gramíneas $\mathrm{C}_{3}$ dominaron la respuesta de la biomasa, de las cuales el "Bottlebrush squirreltail" (Elymus elymoides (Raf.) Swezey ssp. elymoides) fue el principal contribuyente. Las gramíneas $\mathrm{C}_{4}$ tuvieron una mínima respuesta a los tratamientos de restauración, posiblemente porque ellas fueron menos abundantes antes de que el experimento comenzará o porque ellas fueron afectadas adversamente por la quema de otoño. Las leguminosas y hierbas mostraron un retrazo de 4-5 años para responder a los tratamientos de aclareo y compuesto. Aproximadamente 5 años después de implementar el tratamiento compuesto las plantas anuales y bianuales mostraron un gran aumento de la biomasa. La meta de restauración de optimizar la biomasa herbácea debe ser ponderada contra las metas de incrementar la abundancia de grupos funcionales específicos, aumentando la biodiversidad o las plantas raras y manejar las especies vegetales invasoras.

Key Words: understory production, overstory-understory relationships, thinning, prescribed fire, ecological restoration, Pinus ponderosa, Southwest, Gus Pearson Natural Area

Nomenclature: National PLANTS Database (USDA NRCS, 2004)

Funding was provided by a National Science Foundation grant (DEB-9322706), McIntire-Stennis appropriations to the Northern Arizona University School of Forestry, and the Ecological Restoration Institute. Funding for remeasurement and analysis in 2004 was provided by the US Dept of Agriculture Forest Service (03-DG-11031600-088).

Correspondence: Margaret M. Moore, Box 15018, School of Forestry, Northern Arizona University, Flagstaff, AZ 86011. E-mail: Margaret.Moore@nau.edu

Manuscript received 2 March 2005; manuscript accepted 14 November 2005. 


\section{INTRODUCTION}

Prior to Euro-American settlement, southwestern ponderosa pine (Pinus ponderosa P. \& C. Lawson var. scopulorum Engelm.) forests were characterized by a productive, grassdominated understory and a temporary accumulation of litter and woody debris that supported low-intensity surface fires every 2-20 years (Pyne et al. 1996; Swetnam and Baisan 1996, 2003). Euro-American settlement greatly altered these forests at the beginning of the 20th century by introducing large numbers of domestic livestock, removing many large-diameter trees through high-grade logging practices, and disrupting the natural fire regime (Pearson 1910; Weaver 1951; Moore et al. 1999). These factors, combined with favorable climatic conditions, resulted in the establishment of massive amounts of pine regeneration in the early 1900s (Arnold 1950; Weaver 1951; Cooper 1960; Savage and Swetnam 1990; Savage et al. 1996).

Historically, many sites in northern Arizona were described as a matrix of grass-dominated meadows interspersed with stands of pine (Pearson 1950; Cooper 1960). However, contemporary southwestern ponderosa pine forests have a closed overstory canopy with a few fragmented, remnant grass openings intermixed (Covington and Moore 1994; Covington et al. 1997). These remnant grass patches may hold only a fraction of their presettlement plant richness and diversity.

Resource management and conservation practices are challenging in these mixed woody-herbaceous systems (House et al. 2003). The ratio of woody to herbaceous plants is very dynamic and can change at decadal time scales (Archer 1996), especially in response to fire, herbivory, and climate. In response to concerns about forest ecosystem health and large crown fires in southwestern ponderosa pine forests, land managers and the scientific community in the Southwest have begun using ecological restoration thinning treatments to convert dense, closed-canopy ponderosa pine stands back to more open-stand structures. Many of these treatments and management plans also call for regularly scheduled prescribed fires, in hopes of simulating the frequent fire regime that was common in these systems in presettlement times (Agee 1993; Covington et al. 1997; Moore et al. 1999; Wienk et al. 2004). Both overstory tree thinning and prescribed burning can have mixed results on the herbaceous understory, depending upon thinning level and fire intensity, frequency, and season (Covington et al. 1997; Tiedemann et al. 2000; Wienk et al. 2004).

This study is part of a larger project initiated to restore a reasonable approximation of the presettlement ponderosa pine ecosystem and to determine the attributes that characterize the health of that system (Covington et al. 1997; Kaye et al. 2005). Three treatments-thinning from below (thinning restoration treatment), thinning from below with forest floor manipulation and periodic prescribed burning (composite restoration treatment), and no treatment (control)-were applied at the study site. Both restoration treatments return the overstory to the approximate stand structure (size, density, age distributions) of presettlement forests. The composite restoration treatment also restores the approximate fuel depth and fire characteristics of presettlement forests in the area (Covington et al. 1997).
The primary objective of this study was to evaluate the responses of the herbaceous community to the thinning and composite restoration treatments. Here we describe the effects of tree thinning and thinning plus prescribed burning on aboveground herbaceous standing crop by treatment and by plant functional group. Aboveground herbaceous standing crop was measured in 1992 (pretreatment) and another 7 times from 1994-2004 (posttreatment). Treatment differences were assessed with respect to total standing crop and the relative contributions of $\mathrm{C}_{3}$ graminoid, $\mathrm{C}_{4}$ graminoid, legume, nonleguminous perennial forb, and nonleguminous annual-biennial forb functional groups.

\section{METHODS}

\section{Study Site}

This study was conducted at the Gus Pearson Natural Area (GPNA), located approximately $10 \mathrm{~km}$ northwest of Flagstaff, Arizona in the Fort Valley Experimental Forest, Coconino National Forest (lat $35^{\circ} 16^{\prime} 00^{\prime \prime}$, long $\left.111^{\circ} 45^{\prime} 00^{\prime \prime}\right)$. The approximately 4.3-ha study site ranges from 2195 to $2255 \mathrm{~m}$ in elevation, and much of the area has flat to gently rolling topography with some southwesterly and northwesterly aspects. Soils are derived from Tertiary basalt flows and cinders, and are classified as a Brolliar stony clay loam, and a complex of fine, smectitic Typic Argiborolls and Mollic Eutroboralfs (Kerns et al. 2003).

The average annual temperature is $7.5^{\circ} \mathrm{C}$. Average annual precipitation is approximately $57 \mathrm{~cm}$, and follows a bimodal, monsoonal precipitation pattern with approximately half of the precipitation occurring as rain in July and August and half as snow in the winter (Savage et al. 1996). Drought was common during this study, with 2002 being especially severe (Fig. 1). Weather data were obtained from the Fort Valley Experimental Station weather records (USDA, Forest Service Rocky Mountain Research Station 2005), supplemented by data from the Flagstaff airport (NOAA 2005) when data were missing from Fort Valley.

The study area was fenced to exclude domestic ungulates in 1950 , and so has been ungrazed by livestock for more than 50 years (Olberding 2000). In 1992, a 2.4-m electrified fence was constructed to exclude wild ungulates from GPNA. Some trees were removed from GPNA in 1894, but it did not receive commercial harvest after that time (Avery et al. 1976). The last major fire in the vicinity prior to this experiment occurred in 1876 (Dietrich 1980).

Ponderosa pine is the only overstory species on the study site. The understory is dominated by native perennial graminoid species, including Festuca arizonica Vasey (Arizona fescue), Elymus elymoides (Raf.) Swezey ssp. elymoides (bottlebrush squirreltail), Mublenbergia montana (Nutt.) A. S. Hitchc. (mountain muhly), Poa fendleriana (Steud.) Vasey (muttongrass), and Carex geophila Mackenzie (White Mountain sedge). Dominant native perennial forb species include Vicia americana Muhl. Ex. Willd. (American vetch), Senecio actinella Greene (Flagstaff ragwort), Houstonia wrightii Gray (pygmy bluet), Astragalus rusbyi Greene (Rusby's milkvetch), Lupinus argenteus Pursh (silvery lupine), Antennaria parvifolia Nutt. (small-leaf pussytoes), Solidago velutina DC. (threenerve 
goldenrod), Achillea millefolium L. var. occidentalis DC. (western yarrow), and Cirsium wheeleri (Gray) Petrak (Wheeler's thistle). Common native annuals include Mublenbergia minutissima (Steud.) Swallen (annual muhly; a grass), Lupinus kingii S. Wats. (King's lupine; a legume), and forbs such as Laennecia schiedeana (Less.) Cronq. (pineland marshtail), Chenopodium graveolens Willd. (fetid goosefoot), Conyza canadensis (L.) Cronq. (Canadian horseweed), and Helianthus annuus L. (common sunflower). Common native biennial forbs are Erigeron flagellaris Gray (trailing fleabane) and Erigeron divergens Torr. \& Gray (spreading fleabane). Six exotic species have been recorded on the study site, with the 2 dominants being the perennial graminoid Poa pratensis L. (Kentucky bluegrass) and the biennial forb Verbascum thapsus L. (common mullein). The only shrub on the study site is Ceanothus fendleri Gray (Fendler's ceanothus).

\section{Experimental Design}

In 1992, 15 treatment plots, each approximately $0.2-0.3$ ha in size, were established and assigned to one of 3 treatments (control, thinning restoration, and composite restoration treatments). Treatment plots have also been referred to as whole plots (sensu Covington et al. 1997). The 5 control treatment plots were located nonrandomly on one side of the study site, and the thinning and composite treatment plots were assigned randomly. This design was necessary so that the fuel break created by the treated plots would protect the historical buildings of the adjacent Fort Valley Experimental Station.

Each treatment plot contained 4 patch types: presettlement tree groups, thinned postsettlement tree groups, unthinned postsettlement trees, and remnant grass openings. One circular subplot, with a radius of $2.5 \mathrm{~m}$, was established within each of the 4 patch types per treatment plot. In total, 55 subplots were established: 4 per treatment plot in the thinning treatment $(n=20)$ and composite treatment $(n=20)$, and 3 per treatment plot in the control $(n=15$, controls did not contain thinned patches). Subplots represent the range of patch types and illustrate the wide range of conditions sampled within treatment plots. Herbaceous data were scaled to the treatmentplot level $(n=15)$ by weighting the herbaceous standing crop on each subplot by the proportion of the treatment plot area occupied by the patch type in which the subplot was located (see Standing-Crop Data Collection below). Detailed results on patch-level effects can be found in Casey (2004) and Laughlin et al. (2006).

The thinning and composite treatments were thinned from below (i.e., postsettlement trees that were overtopped or in lower crown positions were removed in varying proportions; Nyland 1996) in the fall of 1993, retaining all presettlement trees $(>40.6 \mathrm{~cm}$ diameter at breast height [dbh]) and leaving approximately 3 replacement postsettlement trees for every dead presettlement tree or stump (Fulé et al. 1997; Mast et al. 1999). Presettlement and postsettlement tree group structure was determined through dendrochronological reconstructions (Mast et al. 1999). The thinning and composite treatments removed approximately 2200 trees per hectare (Covington et al. 1997; Fig. 2), including most of the trees that established after 1876 (defined as postsettlement). All slash was removed by hand, and all presettlement coarse woody debris was retained.

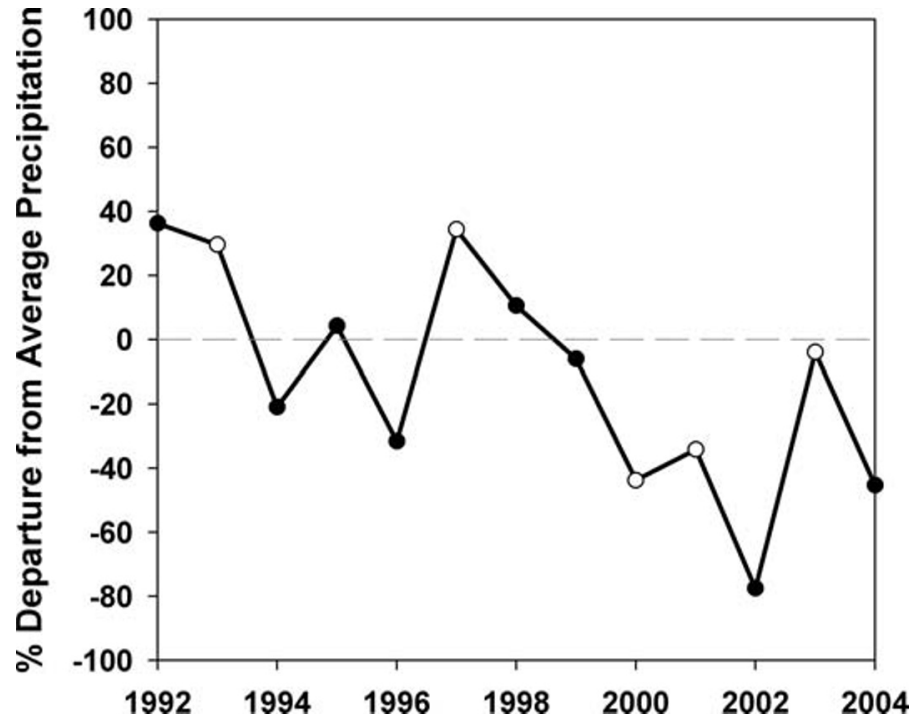

Figure 1. Annual precipitation during the study (1992-2004) as percent departure from the long-term (51-year) average. Annual totals included the 12 months of precipitation before vegetation sampling (previous September through August). Dark symbols indicate years in which vegetation was sampled.

In the composite treatment, the forest floor was manipulated by raking the litter layer aside, removing accumulated forest floor duff, and returning the current (approximately 3-year) litter layer to the site. To simulate the presettlement condition of a grass-dominated understory that carried frequent fire, approximately $670 \mathrm{~kg} \cdot \mathrm{ha}^{-1}$ of herbaceous vegetation from Hart Prairie $(4.8 \mathrm{~km}$ to the north) was harvested in late September 1994 and scattered across the plots (Covington et al. 1997); this supplementation occurred only in 1994. The composite treatment received an initial prescribed burn in 1994, and additional prescribed burns in 1998 and 2002. All burns were conducted in October, after data collection was completed for that year. Fire history records indicate that most presettlement fires in northern Arizona ponderosa pine forests occurred in April through early July (Baisan and Swetnam 1990). Therefore, although fine-fuels loads mimic presettlement herbaceous fuels, the season of burn is not similar to presettlement fire regimes. Contemporary forest fuel loads and conditions often restrict prescribed burns to the fall. Fire intensity was low for all fires, with average flame lengths of $15 \mathrm{~cm}$ and soil surface temperatures of $240^{\circ} \mathrm{C}$.

See Covington et al. (1997) and subsequent publications for a more detailed account of experimental design, thinning and prescribed burn characteristics, treatment protocol, and effects on other ecosystem components (Feeney et al. 1998; Kolb et al. 1998; Kaye and Hart 1998a, 1998b; Kaye et al. 1999; Mast et al. 1999; Skov et al. 2004; Boyle et al. 2005; Kaye et al. 2005).

\section{Standing-Crop Data Collection}

Herbaceous standing-crop data were collected in 1992 (pretreatment), 1994, 1995, 1996, 1998, 1999, 2002, and 2004. Field sampling occurred during a 2 -week period near midSeptember, which is the time of peak aboveground production and flowering for major understory species in northern Arizona (Clary 1975). Each year, we sampled $21-\mathrm{m}^{2}(0.5 \times 2.0 \mathrm{~m})$ 

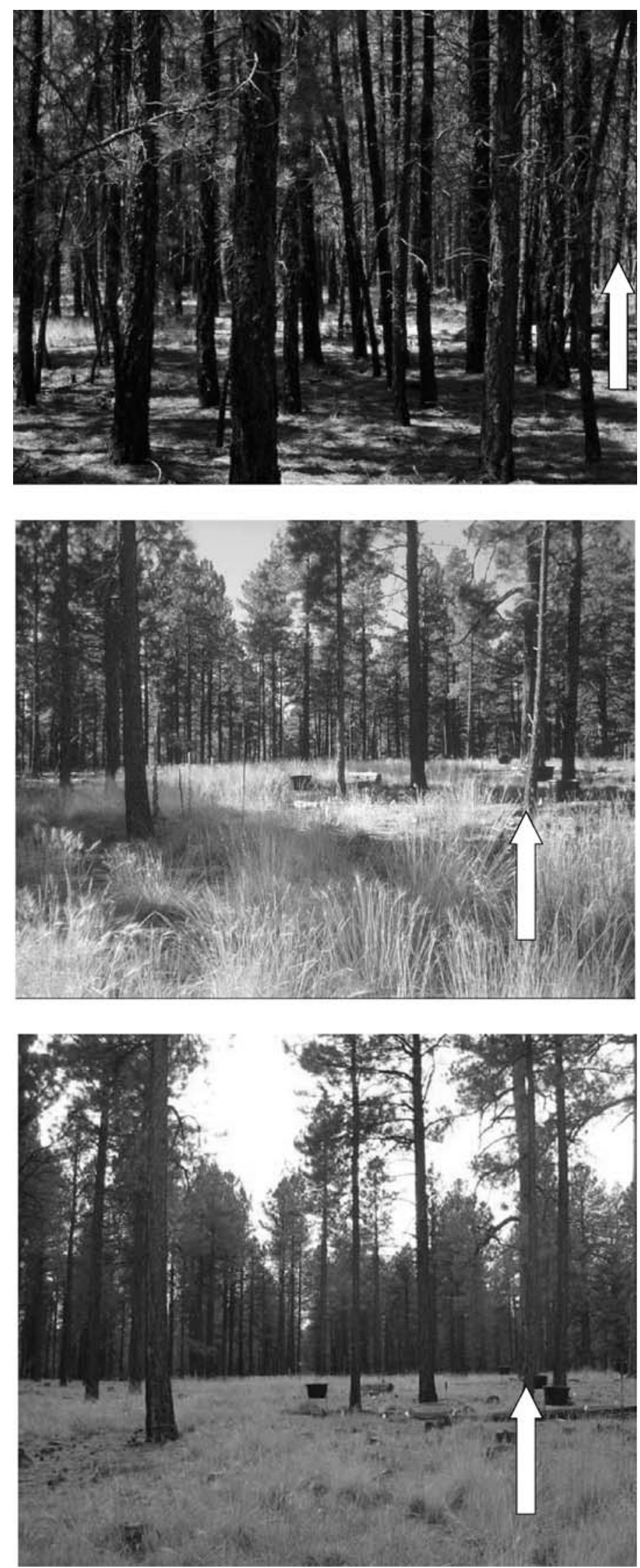

Figure 2. Time-series photographs of photo point 302 prior to treatment (1992, top photo), 5 years after thinning (1998, middle photo), and 11 years after thinning (2004, bottom photo). The arrows highlight the quadrats per circular subplot. All live herbaceous vegetation rooted in the quadrats was clipped to ground level (approximately 2-cm stubble height). Quadrats were arranged in a wagon-wheel configuration around the center of the circular subplot and clipping was rotated each year so that the identical area was not sampled (clipped) for at least 4 years.

Clipped vegetation was separated by species in the field and later regrouped into functional groups. The functional groups differed among years as methods were refined. In 1992, standing crop was separated into graminoid and forb functional groups. From 1994 to 2004, herbaceous vegetation was divided into $\mathrm{C}_{3}$ graminoids (grasses and sedges), $\mathrm{C}_{4}$ graminoids, legumes, nonleguminous perennial forbs, and nonleguminous annualbiennial forbs.

Samples were oven-dried at $70^{\circ} \mathrm{C}$ for $24-48$ hours and weighed to the nearest $0.01 \mathrm{~g}$. Data from the 2 quadrats per subplot were averaged together to yield a single value for each functional group on each of the 55 subplots each year. Herbaceous data were then scaled to the treatment-plot level $(n=15)$.

\section{Statistical Analyses}

Standing-crop data were scaled to the treatment-plot level $(n=5$ per treatment) and analyzed in total and for each functional group. Testing for normality and homogeneity of variances concluded that data were not normally distributed, so they were $\ln (\mathrm{x})$ transformed prior to analysis; annual-biennial forb standing crop was $\ln (\mathrm{x}+1)$ transformed to account for zeros. Treatment effects were compared in 1992 (pretreatment) using a 1-way analysis of variance (ANOVA). Posttreatment standingcrop data (1994-2004) were analyzed using repeated measures multivariate analysis of variance (MANOVA) with GreenhouseGeisser adjustments to account for autocorrelation (Moser et al. 1990). Significant treatment effects in the MANOVA were followed by analyses comparing treatments within each year using 1-way ANOVA and Tukey's honestly significant difference (HSD) post hoc multiple comparisons tests. Significant interactions indicated that treatments differed temporally (significant differences among treatments in interannual variability in standing crop over time). All tests were conducted at $\alpha=0.05$ using JMP-IN software (version 5.1.2; SAS 2004).

We also calculated the proportion that each functional group represented of the total herbaceous standing crop by treatment from 1994-2004. These proportions were compared between treatments using the likelihood ratio contingency test $\left(G^{2}\right)$.

\section{RESULTS}

\section{Total Herbaceous Standing Crop}

After treatment, total standing crop differed significantly among treatments $(F=8.6, P=0.005)$ and over time $(F=27.0$,

same tree (approximately $15 \mathrm{~cm}$ diameter at breast height) in each photo. All photos were taken in early autumn (September to early October) on the Gus Pearson Natural Area near Flagstaff, AZ. Note the difference in herbaceous standing crop between 1998, an average year in precipitation, and 2004, which was $>40 \%$ below normal. (Photo credits: Ecological Restoration Institute, Northern Arizona University) 
$P<0.001$ ) (Fig. 3). The treatment $\times$ time (time since treatment) interaction was also significant $(F=3.0, P=0.015)$.

One-way ANOVA indicated that total standing crop differed marginally among treatments 1 growing season after thinning from below (1994: $F=3.5, P=0.06$ ), and differed significantly among treatments in all subsequent years (all $F>6.3$, all $P<0.02$ ). In particular, total standing crop was higher in both treated areas than in the control, but it never differed between the thinning and composite treatments (Fig. 3).

\section{Graminoid Standing Crop}

After treatment, graminoid standing crop differed among treatments $(F=11.3, P=0.001)$ and over time $(F=13.4$, $P<0.0001)$, and the treatment $\times$ time interaction was also significant $(F=2.4, P=0.04)$. Graminoid standing crop was significantly higher in treated than in control plots in every posttreatment year, but never differed between the thinning and composite treatments.

Graminoids were separated into $\mathrm{C}_{3}$ and $\mathrm{C}_{4}$ graminoids in the years 1994-2004. $\mathrm{C}_{3}$ graminoids had a greater response to treatment than did $\mathrm{C}_{4}$ graminoids (Figs. $4 \mathrm{a}, 4 \mathrm{~b}$, and 5). $\mathrm{C}_{3}$ graminoid standing crop differed by treatment and over time, and the treatment $\times$ time interaction was marginally significant. $\mathrm{C}_{3}$ graminoid standing crop differed between the treated areas and the control in every posttreatment year, but did not differ between thinning and composite treatments (Fig. 4a). $\mathrm{C}_{4}$ graminoid standing crop did not differ among treatments, times, or with the treatment $\times$ time interaction (Fig. 4b).

\section{Forb Standing Crop}

Forb standing crop differed by treatment $(F=4.2, P=0.04)$ and time $(F=42.0, P<0.0001)$, and there was a significant treatment $\times$ time interaction $(F=2.4, P=0.03)$. Forb standing crop did not differ among the 3 treatments from 1994 to 1996 (all $F$ less than 2.5 , all $P>0.1$ ), but did differ from 19982004 (all $F>5.5$, all $P<0.02$ ). Forb standing crop never differed between thinning and composite treatments.

Legumes and annual-biennial forbs had a greater response to treatments than did nonleguminous perennial forbs (Figs. 4c$4 \mathrm{e})$. Legume standing crop differed by treatment, by time, and there was a marginally significant treatment $\times$ time interaction. Legume standing crop in the 2 treated areas differed from the control in every year from 1996-2004 (Fig. 4c). Legume standing crop peaked in 1999, which was 1 year after the 1998 prescribed burn, then declined. Legumes were higher in the composite than in the thinning treatment throughout the study period, though this difference was not statistically significant. Perennial forb standing crop did not differ by treatment, or time, and there was not a significant treatment $\times$ time interaction (Fig. $4 d$ ).

Annual-biennial forb standing crop differed by treatment and by time, and there was a treatment $\times$ time interaction. Annual-biennial forb standing crop was greater in the composite treatment than in the thinning treatment or control from 1999-2004 (Fig. 4e). This functional group peaked in 1999, following the second prescribed burn, and then declined.

\section{Proportions of Functional Groups}

In 1994, proportions of functional groups differed between treatments $\left(\mathrm{G}^{2}=25.5, P=0.0013\right)$; the thinning and com-

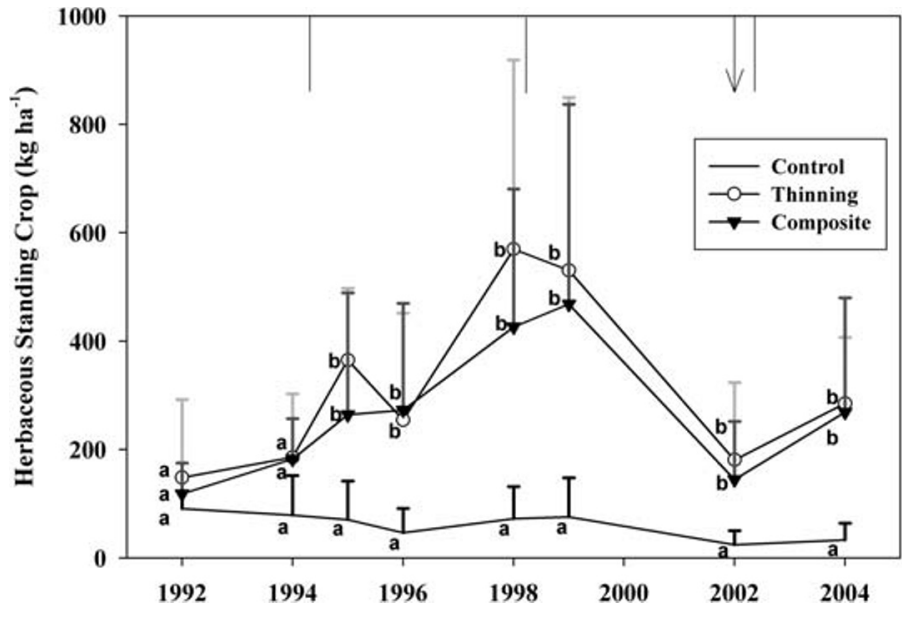

Figure 3. Total herbaceous standing crop (mean $+\mathrm{SD}$ ) in 3 restoration treatments between 1992 and 2004. Data from 1992 represent pretreatment data. Lowercase letters indicate significant differences among treatments within years. The arrow denotes the extreme drought year (2002) and vertical lines denote prescribed burn years.

posite treatments differed from the control (both $P<0.05$ ), but did not differ from each other $(P=0.37)$. In 2004, proportions of functional groups differed between treatments $\left(\mathrm{G}^{2}=72.0, P<0.0001\right)$. In contrast to 1994 , however, the thinning and composite treatments differed from the control and from each other.

In 1994, 1 year after thinning but prior to any prescribed burn, $\mathrm{C}_{3}$ graminoids represented $43 \%$ of the total herbaceous standing crop in the control, $58 \%$ in the thinning, and $67 \%$ in the composite treatment (Fig. 5). These proportions varied over time, with a noted decrease around 1999 , but the $\mathrm{C}_{3}$ graminoid functional group remained dominant in all treatments in 2004 $(51 \%, 60 \%$, and $75 \%$ in the control, thinning, and composite treatments, respectively).

In $1994, \mathrm{C}_{4}$ graminoids represented less than $12 \%$ in the control and thinning treatments, and $6 \%$ in the composite treatment (Fig. 5). Again, these proportions varied over time, with a noted decrease around 1999 . In 2004, $\mathrm{C}_{4}$ graminoids represented $13 \%$ of the total herbaceous standing crop in the control, $26 \%$ in the thinning, and $5 \%$ in the composite treatment.

Perennial forbs comprised the largest proportion of the forb functional group and were $42 \%, 22 \%$, and $17 \%$ of the total herbaceous standing crop in the control, thinning, and composite treatments, respectively, in 1994 (Fig. 5). By, 2004, this group was $35 \%, 9 \%$, and $4 \%$ in the control, thinning, and composite treatments, respectively. Legumes represented 3\%, $8 \%$, and $10 \%$ of the total standing crop in the control, thinning, and composite treatments, respectively, in 1994 (Fig. 5). These proportions varied over time, but by 2004, the legumes accounted for less than $1 \%, 5 \%$, and $8 \%$ of the total standing crop in the control, thinning, and composite treatments, respectively.

Annual and biennial forbs were negligible in 1994 in the control and represented less than $1 \%$ of the total standing crop in both the thinning and composite treatments (Fig. 5). In 1999, annual-biennial forbs were $1 \%$ and $2 \%$ in the control and thinning treatment, respectively, but $20 \%$ in the composite treatment. In 2004, annual-biennial forbs continued to account for less than $1 \%$ of the total standing crop in the control and 


\section{Graminoids}
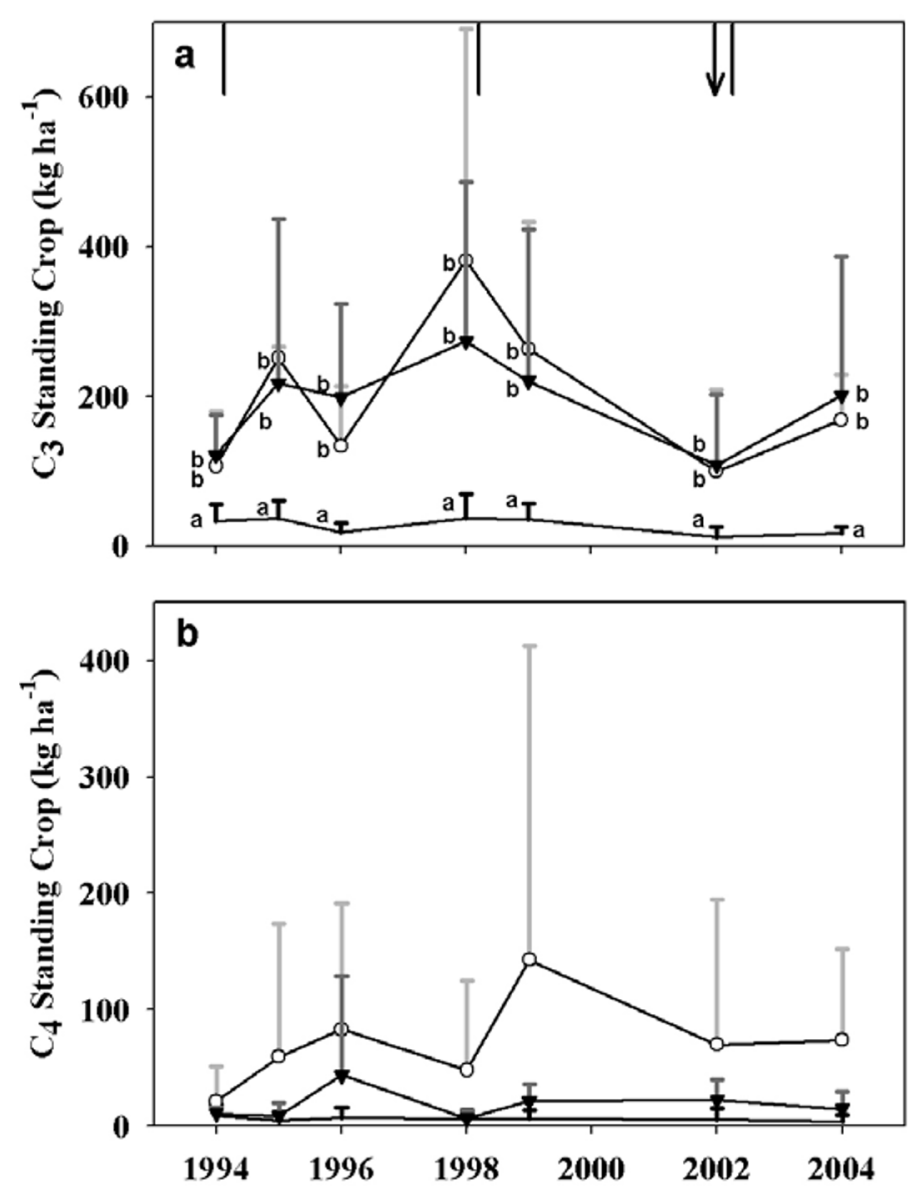

Forbs
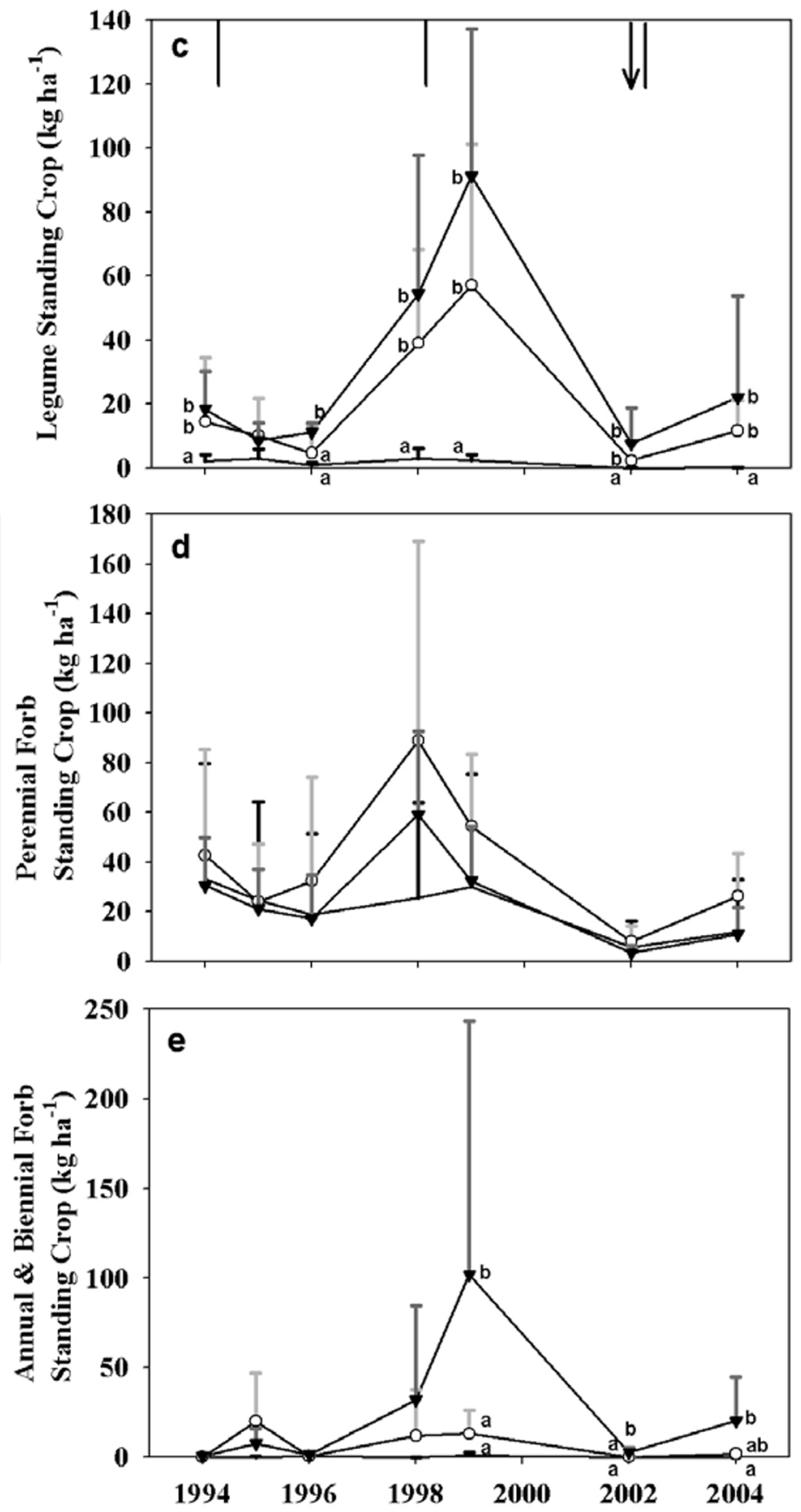

Figure 4. Standing crop (mean $+\mathrm{SD}$ ) of: a) $\mathrm{C}_{3}$ graminoids, b) $\mathrm{C}_{4}$ graminoids, c) legumes, d) nonleguminous perennial forbs, and e) nonleguminous annual-biennial forbs in 3 restoration treatments between 1994 and 2004. Lowercase letters indicate significant differences between treatments within years; letters are not shown if treatments did not differ. The arrow denotes the extreme drought year (2002) and vertical lines denote prescribed burn years. Note differences in scale of the y-axis among graphs.

thinning treatments, but represented $7 \%$ of the total standing crop in the composite treatment.

\section{DISCUSSION}

The thinning and composite restoration treatments increased total herbaceous standing crop significantly over the control. Total herbaceous standing crop in the thinning and composite restoration treatments significantly increased just 2 years after thinning and reached a maximum (approximately 5 -fold over the control) in 1998 and 1999. This immediate response in herbaceous standing crop was because of the $\mathrm{C}_{3}$ graminoid component of the understory. Forbs responded later, 5 to 6 years after the initial thinning and prescribed burning. Precipitation and drought patterns greatly influenced herbaceous standing crop (see Drought Effects below). 

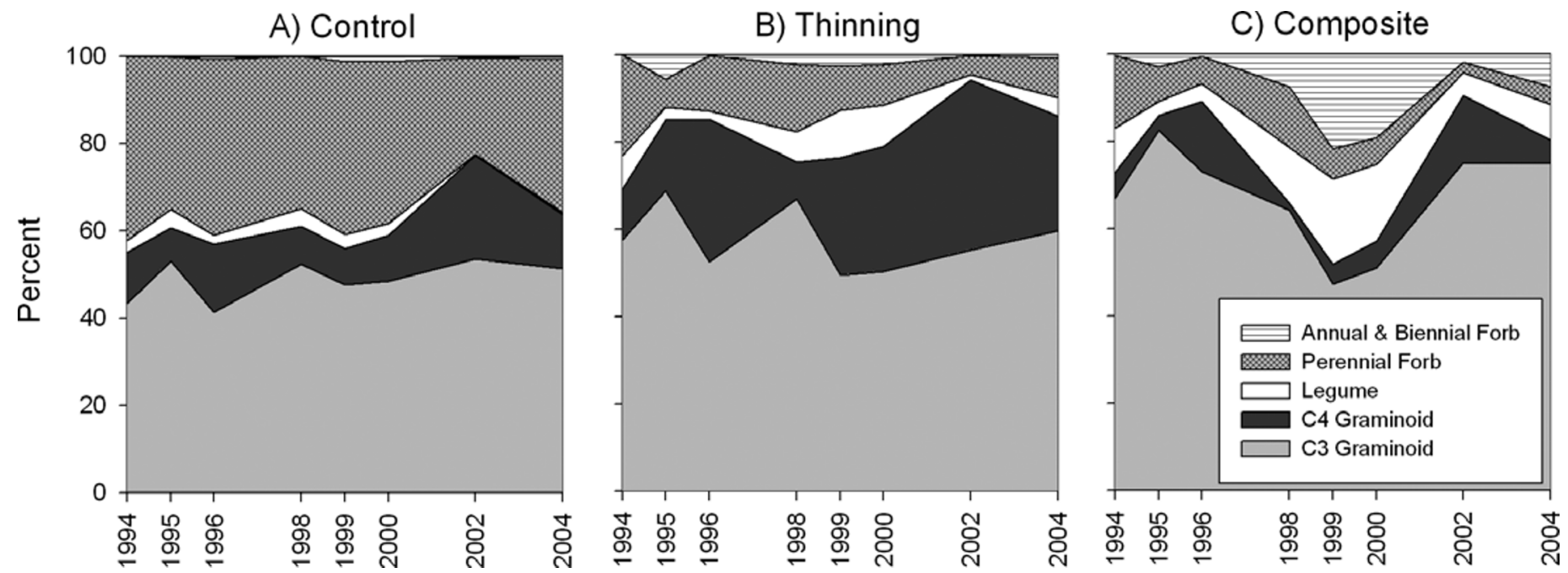

Figure 5. Distribution of total standing crop among functional groups in: A) control, B) thinning, and C) composite restoration treatments between 1994 and 2004.

\section{Thinning Effects}

Herbaceous $\mathrm{C}_{3}$ graminoids and legumes demonstrated an immediate response to thinning. Our results are consistent with other overstory-understory studies in ponderosa pine forests and pine-oak woodlands that demonstrate that high overstory canopy cover results in low herbaceous production (Arnold 1950), and that rapid recovery of understory plant biomass can be obtained by basal area reduction (Thompson and Gartner 1971; Ffolliott and Clary 1982; Uresk and Severson 1989; McPherson and Weltzin 1998; Wienk et al. 2004). Increased light availability, resulting from tree thinning, was likely the main factor stimulating increased herbaceous standing crop (McLaughlin 1978; Riegel et al. 1995; Naumberg et al. 2001), in addition to higher nitrogen and water availability (Riegel et al. 1995; Kaye et al. 2005).

$\mathrm{C}_{3}$ graminoid standing crop responded quickly to overstory thinning, but $\mathrm{C}_{4}$ graminoid standing crop responded only slightly to thinning even 11 years after treatment. These results are inconsistent with reports of greater $\mathrm{C}_{4}$ graminoid response following overstory canopy removal (Thompson and Gartner 1971; McPherson and Weltzin 1998). This apparent discrepancy might reflect differential responses among individual plant species within each functional group. In our study, for example, the native perennial bottlebrush squirreltail (a $\mathrm{C}_{3}$ graminoid), dominated the initial herbaceous standing crop response to thinning (Casey 2004; Laughlin et al. 2006). Squirreltail can colonize sites quickly and it performs well in a variety of light conditions (Vose and White 1991; Jones 1998; Naumberg and DeWald 1999; Naumberg et al. 2001).

Unique functional-group responses compared to other investigations may also reflect the existence of different initial conditions. For example, the initial proportion of $\mathrm{C}_{4}$ graminoids in our experiment was low $(<12 \%$ of total standing crop in 1994) relative to $C_{3}$ graminoids in all treatments. In contrast, the study by McPherson and Weltzin (1998) was conducted in southern Arizona, where $\mathrm{C}_{4}$ grass species dominate $(>90 \%$ of total herbaceous biomass at experiment initiation) and $\mathrm{C}_{3}$ grass species are sparse. Although little is known about the importance of graminoid functional groups in presettlement forests, it is possible that $\mathrm{C}_{4}$ graminoids, which are shade-intolerant, have been locally extirpated beneath the dense canopies of treed plots (Kerns et al. 2001, 2003). If so, these extinctions would have occurred many years before we initiated this experiment.

Despite the overall poor response of $\mathrm{C}_{4}$ graminoids, we did observe a gradual increase in the proportion of $\mathrm{C}_{4}$ graminoids in the thinning treatment over the 11-year period (Fig. 5). Mountain muhly, which drove this response (Casey 2004; Laughlin et al. 2006), has been shown to increase its biomass with increasing light availability (Naumburg and DeWald 1999; Naumburg et al. 2001).

\section{Fire Effects}

The severity of fire effects on the understory is dependent upon a number of factors, including the frequency, intensity, and season of burning, as well as species composition and abiotic factors. Research has generally shown that understory production increases following low-intensity prescribed burns in ponderosa pine forests, though increases are often species specific (Harris and Covington 1983; Andariese and Covington 1986; Vose and White 1991; Wienk et al. 2004).

In this study, effects of low-intensity autumn prescribed burns on herbaceous standing crop were confounded with overstory canopy reduction and manipulation of the forest floor prior to the first prescribed burn. However, fire may have been a major contributor to some of the functional group changes. $\mathrm{C}_{4}$ graminoids (particularly mountain muhly) did not increase in the composite treatment, suggesting that some aspect of the periodic burning (season, frequency, intensity, etc.) was detrimental to this functional group. Other studies have also shown a decrease in $\mathrm{C}_{4}$ grasses with fall prescribed burns. Gaines et al. (1958) found a $10 \%$ decrease in mountain muhly in ponderosa pine forests 1 year after autumn prescribed burns in eastern Arizona. Haisley (1984) found that mountain muhly production significantly decreased in aspen and ponderosa pine forests of northern Arizona after October prescribed burns.

The increase in $\mathrm{C}_{3}$ graminoids (specifically bottlebrush squirreltail), legumes, and annual-biennial forbs in the more 
disturbed environment of the composite treatment was not surprising. Low-intensity fire creates conditions suitable for early successional species by increasing bare ground for germination sites, increasing short-term nutrient availability, and removing dominant competitors (Denslow 1983; Collins and Gibson 1990; Whelan 1995; Crawford et al. 2001). Bottlebrush squirreltail is an early and rapid colonizer of disturbed sites (Jones 1998) and generally increases following low-intensity fall burns (Young and Miller 1985).

Legumes showed a delay in response to restoration treatments for the first 4 years, and then increased substantially in 1998 in both treated areas, suggesting that both restoration treatments affected legume production. Legumes are common in fire-dependent communities (Leach and Givnish 1996), and are known colonizers and increasers following fire. In the southeastern United States, frequently burned sites were reported to have a higher frequency, density, and diversity of legumes than did unburned sites (Hendricks and Boring 1999).

Annual and biennial forbs had a delayed response to treatment, similar to that observed in legumes and perennial forbs, and then showed a standing-crop increase in 1998 in both treatments. However, the largest increase occurred in 1999, 1 year after the second prescribed burn, when annual and biennial forb standing crop was significantly higher in the composite treatment than in the thinning treatment or control. By 2002, standing crop of this functional group had returned to earlier levels. Note that precipitation was near normal or above average during the first 5-6 years and then below average during the last 5 years. It is not surprising to find more annuals and biennials in a disturbed environment that includes frequent surface fires that consume most of the surface litter, leaving a suitable environment for the establishment of ruderal species. Common mullein, an exotic biennial, drove the annualbiennial standing crop response (Casey 2004). The dominant native annual and biennial forbs were pineland marshtail and 2 species of fleabane. Mullein and pineland marshtail seeds are commonly found in the soil seed bank of ponderosa pine forests in northern Arizona following thinning or burning treatments (Korb et al. 2004, 2005).

The intent of the original study was to mimic the frequency, intensity, and season of burning of the natural fire regime for the study area (Covington et al. 1997). Fire history records indicate that prior to Euro-American settlement of the region, most fires in the ponderosa pine forests of northern Arizona (and in the Southwest in general) occurred in the spring and early summer (April through early July) (Baisan and Swetnam 1990). Spring or early summer fires may suppress $C_{3}$ graminoid and enhance $\mathrm{C}_{4}$ graminoid functional-group responses to a greater extent than those that occurred in response to October burning in this investigation. However, it is currently unsafe to conduct a prescribed burn under the weather and fuels conditions that exist in many areas of northern Arizona between April and early July.

In addition to fire effects, the composite treatment underwent extensive forest floor manipulation before the first burn, including raking to remove the litter layer and the addition of mown hay from a nearby prairie. These activities may have had additional effects on the understory, which were not examined or controlled for in this study. Raking may have affected total standing crop and species composition by affecting the soil seed bank in the $\mathrm{O}$ horizon of the composite treatment (Korb et al. 2004, 2005). Although it is theoretically possible to introduce plant species by the addition of mown prairie hay, our plant surveys have not revealed any new species over the years (Casey 2004). This procedure has not been observed to result in any plant introductions in the northern Great Plains (Bakker et al. 2003). If forest floor manipulation activities are to become an integral process in restoration, they should be examined as separate treatments in future studies to determine their unique impacts.

\section{Drought Effects}

Precipitation and drought appear to be the primary forcing factors in total herbaceous standing crop in our study. Drought was common, especially during the last 5 years (Fig. 1), and severe, particularly in 2002, when precipitation was $75 \%$ below average. These droughts reduced herbaceous standing crop to levels that were similar to 1992 and $1994 . \mathrm{C}_{4}$ graminoids were not as greatly affected by the drought as were the other functional groups. McPherson and Weltzin (1998) also report the recovery of $\mathrm{C}_{4}$ species the second year after overstory canopy removal, even with below-average precipitation. The greater water-use efficiency of $\mathrm{C}_{4}$ plants likely explains their ability to thrive under drought-stressed conditions (Waller and Lewis 1979; Ehleringer and Monson 1993). We suspect that when normal precipitation resumes in northern Arizona, total standing crop in both treated areas will eventually exceed the maximum experienced in 1998.

\section{CONCLUSIONS AND MANAGEMENT IMPLICATIONS}

The herbaceous understory should be a prime focus of land managers involved with forest restoration and conservation biology activities in southwestern ponderosa pine forests. A productive and diverse understory protects soil from erosion, creates forage and cover for livestock and wildlife, provides fuels for surface fires, and is the repository for much of the plant biodiversity in these ecosystems. Successful restoration projects should seek to enhance the recovery of native herbaceous species.

These results demonstrate that restoration treatments that reduce dominance of the overstory canopy increase total herbaceous standing crop of the understory in ponderosa pine forests of northern Arizona. A long-term perspective is required to assess treatment responses as evidenced by the unique temporal responses among plant functional groups and the disproportionate impact of severe drought on $\mathrm{C}_{3}$ compared to $\mathrm{C}_{4}$ graminoid plant functional groups during the 11-year investigation. Graminoid standing crop responded within several years of the initial treatments and increased over time until a severe drought reduced standing crop to levels near those present when the experiment began. $\mathrm{C}_{3}$ graminoids, particularly bottlebrush squirreltail, dominated this standing-crop response. $\mathrm{C}_{4}$ graminoids, on the other hand, showed a minimal response to restoration treatments. The limited response of $\mathrm{C}_{4}$ graminoids to restoration treatment may reflect their limited abundance at the time of pretreatment. The abundance of this functional group may have been suppressed because of its 
inability to grow and reproduce under dense tree shade. However, it also appears that $\mathrm{C}_{4}$ graminoids were adversely affected by autumn burning. Legumes and forbs showed a significant 4-5-year lag before responding to the thinning or composite treatments. There was a large pulse in annual and biennial forbs approximately 5 years after experiment initiation, driven primarily by common mullein, an exotic biennial. The restoration goal of optimizing herbaceous standing crop must be weighed against the competing goals of increasing the abundance of specific functional groups, increasing biodiversity or rare plants, and managing invasive plant species.

\section{ACKNOWLEDGMENTS}

We thank the staff and students of the Ecological Restoration Institute at Northern Arizona University for collecting data, processing samples, and maintaining the database for the GPNA experimental treatments. Particular thanks go to J. Roccaforte, J. Barber, L. Labate, M. Stoddard, L. Machina, M. Daniels, and S. Curran. Thanks to the USDA Forest Service Rocky Mountain Research Station, especially C. Edminster, for helping establish the experiment, and to Coconino National Forest for assistance with prescribed burns. Lastly, we thank the Associate Editor and two anonymous reviewers, whose comments greatly improved this manuscript.

\section{LITERATURE CITED}

AgeE, J. K. 1993. Fire ecology of Pacific Northwest forests. Washington, DC: Island Press. $505 \mathrm{p}$.

Andariese, S. W., And W. W. Covington. 1986. Changes in understory production for three prescribed burns of different ages in ponderosa pine. Forest Ecology and Management 14:193-203.

ARCHER, S. 1996. Assessing and interpreting grass-woody plant dynamics. In: The ecology and management of grazing systems, J. Hodgson and A. Illius [EDS.]. Wallingford, United Kingdom: CAB International. p 101-134.

ARnoLd, J. F. 1950. Changes in ponderosa pine-bunchgrass ranges in northern Arizona resulting from pine regeneration and grazing. Journal of Forestry 48:118-126.

Avery, C. C., F. R. Larson, and G. H. Schubert. 1976. Fifty-year records of virgin stand development in southwestern ponderosa pine. Fort Collins, CO: USDA Forest Service, General Technical Report RM-22. $71 \mathrm{p}$.

Baisan, C. H., AND T. W. Swetnam. 1990. Fire history on a desert mountain range: Rincon Mountain Wilderness, Arizona, U.S.A. Canadian Journal of Forest Research 20:1559-1569.

Bakker, J. D., S. D. Wilson, J. M. Christian, X. Li, L. G. Ambrose, and J. Waddington. 2003. Contingency of grassland restoration on year, site, and competition from introduced grasses. Ecological Applications 13:137-153.

Boyle, S. I., S. C. HaRt, J. P. Kaye, and M. P. Waldrop. 2005. Restoration and canopy type influence soil microflora in a ponderosa pine forest. Soil Science Society of America Journal 69:1627-1638.

CASEY, C. A. 2004. Herbaceous biomass and species composition responses to ponderosa pine restoration treatments. [M.S. thesis]. Flagstaff, AZ: Northern Arizona University. 107 p.

CLARY, W. P. 1975. Range management and its ecological basis in the ponderosa pine type of Arizona: the status of our knowledge. Fort Collins, CO: USDA Forest Service Research Paper RM-158. $35 \mathrm{p}$.

Coluins, S. L., And D. J. Gibson. 1990. Effects of fire in community structure in tallgrass and mixed-grass prairie. In: Fire in North American tallgrass prairie. S. L. Collins and L. L. Wallace [EDS.]. Norman, OK and London, United Kingdom: University of Oklahoma Press. p. 81-98.

COOPER, C. F. 1960. Changes in vegetation, structure, and growth of Southwestern ponderosa pine forests since white settlement. Ecology 42: 493-499.
Covington, W. W., and M. M. Moore. 1994. Southwestern ponderosa forest structure: changes since Euro-American settlement. Journal of Forestry 92:39-47.

Covington, W. W., P. Z. Fulé, M. M. Moore, S. C. Hart, T. E. Kolb, J. N. Mast, S. S. SACKett, and M. R. WaGner. 1997. Restoring ecosystem health in ponderosa pine forests of the Southwest. Journal of Forestry 95:23-29.

Crawford, J. A., C. H. Wahren, S. Kyle, and W. H. Moir. 2001. Responses of exotic plant species to fires in Pinus ponderosa forests in northern Arizona. Journal of Vegetation Science 12:261-268.

DensLow, J. S. 1983. Disturbance-mediated coexistence of species. In: The ecology of natural disturbance and patch dynamics. S. T. A. Pickett and P. S. White [Eds.]. San Diego, CA: Academic Press, Inc. p 307-323.

Dieterich, J. H. 1980. Chimney Spring forest fire history. Fort Collins, CO: USDA Forest Service Research Paper RM-220. 8 p.

EhleRinger, J. R., AND R. K. Monson. 1993. Evolutionary and ecological aspects of photosynthetic pathway variation. Annual Review of Ecology and Systematics 24:411-439.

Feeney, S. R., T. E. Kolb, M. R. Wagner, and W. W. Covington. 1998. Influence of thinning and burning restoration treatments on presettlement ponderosa pines at the Gus Pearson Natural Area. Canadian Journal of Forest Research 28: 1295-1306.

Ffolliot, P. F., and W. P. ClaRy. 1982. Understory-overstory vegetation relationships: an annotated bibliography. Ogden, UT: USDA Forest Service General Technical Report INT-136. $39 \mathrm{p}$.

Fulé, P. Z., W. W. Covington, And M. M. Moore. 1997. Determining reference conditions for ecosystem management of Southwestern ponderosa pine forests. Ecological Applications 7:895-908.

Gaines, E. M., H. R. Kallander, and J. A. Wagner. 1958. Controlled burning in Southwestern ponderosa pine: results from the Blue Mountain plots, Fort Apache Indian Reservation. Journal of Forestry 54:323-327.

HAISLEY, J. R. 1984. The effects of prescribed burning on four aspen-bunchgrass communities in northern Arizona. [M.S. thesis]. Flagstaff, AZ: Northern Arizona University. $52 \mathrm{p}$.

HarRis, G. R., And W. W. Covington. 1983. The effect of prescribed fire on nutrient concentration and biomass of understory vegetation in ponderosa pine. Canadian Journal of Forest Research 13:501-507.

Hendricks, J. J., And L. R. Boring. 1999. $\mathrm{N}_{2}$ fixation by native herbaceous legumes in burned pine ecosystems of southeastern United States. Forest Ecology and Management 113:167-177.

House, J. I., S. Archer, D. D. Breshears, R. J. Scholes, and NCEAS Tree-Grass InTERACTION Participants. 2003. Conundrums in mixed woody-herbaceous plant systems. Journal of Biogeography 30:1763-1777.

JoNES, T. A. 1998. Viewpoint: the present status and future prospects of squirreltail research. Journal of Range Management 51:326-331.

KaYe, J. P., AND S. C. HaRT. 1998a. Ecological restoration alters nitrogen transformations in a ponderosa pine-bunchgrass ecosystem. Ecological Applications 8:1052-1060.

Kaye, J. P., AND S. C. HaRT. 1998b. Restoration and canopy-type effects on soil respiration in a ponderosa pine-bunchgrass ecosystem. Soil Science Society of America Journal 62:1062-1072.

Kaye, J. P., S. C. HaRt, R. C. CobB, and J. E. Stone. 1999. Water and nutrient outflow following the ecological restoration of a ponderosa pine-bunchgrass ecosystem. Restoration Ecology 7:252-261.

Kaye, J. P., S. C. Hart, P. Z. Fulé, W. W. Covington, M. M. Moore, and M. W. Kaye. 2005. Initial carbon, nitrogen, and phosphorus fluxes following ponderosa pine restoration treatments. Ecological Applications 15:1581-1593.

Kerns, B. K., M. M. Moore, and S. C. HaRt. 2001. Estimating forest-grassland dynamics using soil phytolith assemblages and $\delta^{13} \mathrm{C}$ of soil organic matter. EcoScience 8:478-488.

Kerns, B. K., M. M. Moore, M. E. Timpson, and S. C. Hart. 2003. Soil properties associated with vegetation patches in a Pinus ponderosa-bunchgrass mosaic. Western North American Naturalist 63:452-462.

Kolb, T. E., K. M. Holmberg, M. R. Wagner, and J. E. Stone. 1998. Regulation of ponderosa pine foliar physiology and insect resistance mechanisms by basal area treatment. Tree Physiology 18:375-381. 
Korb, J. E., N. C. Johnson, And W. W. Covington. 2004. Slash pile burning effects on soil biotic and chemical properties and plant establishment: recommendations for amelioration. Restoration Ecology 12:52-62.

Korb, J. E., J. D. Springer, S. R. Powers, and M. M. Moore. 2005. Soil seed banks in Pinus ponderosa forests in Arizona: clues to site history and restoration potential. Applied Vegetation Science 8:103-112.

Laughlin, D. C., M. M. Moore, J. D. Bakker, C. A. Casey, J. D. Springer, P. Z. Fulé, and W. W. Covington. 2006. Assessing targets for the restoration of herbaceous vegetation in ponderosa pine forests. Restoration Ecology (in press).

LEACH, M. K., AND T. J. Givnish. 1996. Ecological determinants of species loss in remnant prairies. Science 273:1555-1557.

Mast, J. N., P. Z. Fulé, M. M. Moore, W. W. Covington, and A. E. M. Waltz. 1999. Restoration of presettlement age structure of an Arizona ponderosa pine forest. Ecological Applications 9:228-239.

McLaughlin, S. P. 1978. Overstory attributes, light, throughfall, and the interpretation of overstory-understory relationships. Forest Science 24:550-553.

McPherson, G. R., And J. F. Weltzin. 1998. Herbaceous response to canopy removal in southwestern woodlands. Journal of Range Management51:674-678.

Moore, M. M., W. W. Covington, and P. Z. Fulé. 1999. Reference conditions and ecological restoration: a southwestern ponderosa pine perspective. Ecological Applications 9:1266-1277.

Moser, E. B., A. M. Saxton, and S. R. Pezeshki. 1990. Repeated measures analysis of variance: application to tree research. Canadian Journal of Forest Research 20:524-535.

National Oceanic and Atmospheric Administration [NOAA]. 2005. National Oceanic and Atmospheric Administration. Available at: http://www.noaa.gov, accessed 25 January 2005.

Naumberg, E., and L. E. DeWald. 1999. Relationships between Pinus ponderosa forest structure, light characteristics, and understory graminoid species presence and abundance. Forest Ecology and Management 124:205-215.

Naumburg, E., L. E. DeWald, and T. E. Kolb. 2001. Shade responses of five grasses native to southwestern Pinus ponderosa forests. Canadian Journal of Botany 79:1001-1009.

NyLAND, R. D. 1996. Silviculture: concepts and applications. New York, NY: McGraw-Hill Inc. 633 p.

OLBERDING, S. D. Spring 2000. Fort Valley: the beginnings of forest research. Forest History Today 9-15.

Pearson, G. A. 1910. Reproduction of western yellow pine in the Southwest. Washington, DC: US Forest Service Circular 174. $16 \mathrm{p}$.

Pearson, G. A. 1950. Management of ponderosa pine in the Southwest. Washington, DC: USDA Forest Service, Monograph No. 6. 218 p.

Pyne, S. J., P. L. Andrews, and R. D. Laven. 1996. Introduction to wildland fire. 2nd ed. New York, NY: John Wiley and Sons. $808 \mathrm{p}$.

Riegel, G. M., R. F. Miller, and W. C. Krueger. 1995. The effects of aboveground and belowground competition on understory species composition in a Pinus ponderosa forest. Forest Science 41:864-889.

SAS InSTITUTE, Inc. [computer program] 2004. JMP-IN ver. 5.1.2, Statistical Analysis Software. Cary, NC: SAS Institute Inc.
Savage, M., P. M. Brown, and J. Feddema. 1996. The role of climate in a pine forest regeneration pulse in the southwestern United States. Ecoscience 3:310-318.

Savage, M., and T. W. Swetnam. 1990. Early 19th century fire decline following sheep pasturing in a Navajo ponderosa pine forest. Ecology 71:23742378.

Skov, K. R., T. E. Kolb, and K. F. Wallin. 2004. Tree size and drought affect ponderosa pine physiological response to thinning and burning treatments. Forest Science 50:81-91.

Swetnam, T. W., and C. H. Baisan. 1996. Historical fire regime patterns in the southwestern United States since AD 1700. In: Fire effects in southwestern forests: Proceedings of the 2nd La Mesa Fire Symposium. Fort Collins, CO: USDA Forest Service General Technical Report RM-GTR-286. p 11-32.

Swetnam, T. W., and C. H. Baisan. 2003. Tree-ring reconstructions of fire and climate history in the Sierra Nevada and southwestern United States. In: Fire and climatic change in temperate ecosystems of the western Americas. T. T. Veblen, W. L. Baker, G. Montenegro, and T.W. Swetnam [EDS.]. New York, NY: Springer-Verlag. p. 158-195.

Thompson, W. T., and F. R. Gartner. 1971. Native forage response to clearing low quality ponderosa pine. Journal of Range Management 24:272-277.

Tiedemann, A. R., J. O. Klemmedson, and E. L. Bull. 2000. Solution of forest health problems with prescribed fire: are forest productivity and wildlife at risk? Forest Ecology and Management 127:1-18.

URESK, D. W., AND K. E. SEVERSON. 1989. Understory-overstory relationships in ponderosa pine forests, Black Hills, South Dakota. Journal of Range Management 42:203-208.

USDA, NRCS. 2004. The PLANTS Database, Version 3.5. Baton Rouge, LA: National Plant Data Center. Available at: http://plants.usda.gov. Accessed 10 January 2006.

usda, Forest Service, Rocky Mountain Research Station, Flagstaff, AZ. 2005. Weather data online. Available at: http://www.rmrs.nau.edu/weather. Accessed 25 January, 2005

VoSE, J. M., AND A. S. White. 1991. Biomass mechanisms of understory species the first year after prescribed burning in an Arizona ponderosa pine community. Forest Ecology and Management 40:175-187.

Waller, S. S., And J. K. Lewis. 1979. Occurrence of $C_{3}$ and $C_{4}$ photosynthetic pathways in North American grasses. Journal of Range Management 32:12-28.

WeAVER, H. 1951. Fire as an ecological factor in southwestern ponderosa pine forests. Journal of Forestry 49:93-98.

WheLAn, R. J. 1995. The ecology of fire. Cambridge, United Kingdom: Cambridge University Press. 356 p.

Wienk, C. L., C. H. Sieg, And G. R. McPherson. 2004. Evaluating the role of cutting treatments, fire and soil seed banks in an experimental framework in ponderosa pine forests of the Black Hills, South Dakota. Forest Ecology and Management 192:375-393.

Young, R. P., And R. F. Miller. 1985. Response of Sitanion hystrix (Nutt.) J.G. to prescribed burning. American Midland Naturalist 113:182-187. 